Article

\title{
Flood Susceptibility Mapping on a National Scale in Slovakia Using the Analytical Hierarchy Process
}

\author{
Matej Vojtek *(1) and Jana Vojteková(D) \\ Department of Geography and Regional Development, Faculty of Natural Sciences, Constantine the Philosopher \\ University in Nitra, 94901 Nitra, Slovakia; jvojtekova@ukf.sk \\ * Correspondence: mvojtek@ukf.sk; Tel.: +421376408638
}

Received: 26 January 2019; Accepted: 19 February 2019; Published: 21 February 2019

\begin{abstract}
Flood susceptibility mapping and assessment is an important element of flood prevention and mitigation strategies because it identifies the most vulnerable areas based on physical characteristics that determine the propensity for flooding. This study aims to define the flood susceptibility zones for the territory of Slovakia using a multi-criteria approach, particularly the analytical hierarchy process (AHP) technique, and geographic information systems (GIS). Seven flood conditioning factors were chosen: hydrography—distance from rivers, river network density; hydrology - flow accumulation; morphometry-elevation, slope; and permeability—curve numbers, lithology. All factors were defined as raster datasets with the resolution of $50 \times 50 \mathrm{~m}$. The AHP technique was used to calculate the factor weights. The relative importance of the selected factors prioritized slope degree as the most important factor followed by river network density, distance from rivers, flow accumulation, elevation, curve number, and lithology. It was found that $33.1 \%$ of the territory of Slovakia is characterized by very high to high flood susceptibility. The flood susceptibility map was validated against 1513 flood historical points showing very good agreement between the computed susceptibility zones and historical flood events of which $70.9 \%$ were coincident with high and very high susceptibility levels, thus confirming the effectiveness of the methodology adopted.
\end{abstract}

Keywords: flood; susceptibility; Slovakia; analytical hierarchy process; multi-criteria decision analysis; weight linear combination; GIS

\section{Introduction}

Floods have always been a natural part of the hydrological cycle, however, an increasing trend in frequency and magnitude of floods has been recorded in recent decades [1]. Therefore, developing effective flood prevention measures has been a difficult task in many countries, including Slovakia. The increasing trend in the occurrence of flood events is mainly the result of the ongoing climate changes as well as land use changes driven by human activities [2,3]. In addition, anthropogenic impacts often limit the natural retention and transformation capabilities of basins which may result in accelerated surface runoff or erosion processes [4,5].

Mapping and analysis of flood susceptibility is one of the most important elements of early warning systems or strategies for prevention and mitigation of future flood situations since it identifies the most vulnerable areas based on physical conditions that determine the propensity for flooding. Therefore, the term susceptibility can be also perceived as one of the dimensions of vulnerability assessment [6,7].

Generally, flood susceptibility mapping techniques rely on various conditioning factors representing the physical characteristics of the investigated area. These factors usually include geology or lithology, morphometric properties (e.g., elevation, slope), river network density, soil types or hydrological soil groups, land use/land cover, and the like. The selection of conditioning 
factors greatly depends on the spatial scale of the intended flood susceptibility analysis. Basically, if the investigated area is large (e.g., national scale), then using less factors seems to be rational since it is more difficult to gain the same data (same scale or resolution) for the whole territory [7-9]. On the other hand, some studies argue that a limited number of factors may increase the possibility of getting some over-rated factors [10]. In case of local scale studies (e.g., catchment scale), a wider range of location-specific data and factors can be used, allowing for more accurate characterization of the flooding predispositions [11,12].

Since floods are multi-dimensional phenomena with spatial and temporal aspects, geographic information systems (GIS) represent useful tools for the synthesis of different input data and variables using specific logical and mathematical relations to produce flood susceptibility maps [13,14]. In order to identify and assess flood susceptible areas, various methods have been developed and applied in different geographic areas.

One of the methods used for assessing flood susceptibility is multi-criteria decision analysis (MCDA) $[15,16]$. Different approaches for assigning weights (e.g., expert judgement) or weighting methods (e.g., pairwise) can be used in MCDA to prioritize the relative importance of the selected conditioning factors $[10,17]$. Based on a literature review, the most common method of MCDA, in terms of defining flood susceptible zones, is the weighted linear combination approach [18]. Regarding the weight linear combination approach, each conditioning factor is multiplied by its weight and the sum of all investigated conditioning factors represents the final flood susceptibility [19]. The most preferred technique for defining weights is the analytical hierarchy process (AHP) which uses pairwise comparisons in order to find the degree to which one alternative outranks the other on the specified criteria [20].

Several other approaches have been used for mapping flood susceptibility [21]. Methods relying on geomorphologic characteristics of a basin have been used in several studies [22-25]. However, it should be noted that these methods cannot substitute traditional hydraulic modeling [26,27], but they could be used, especially, in large-scale analysis or in developing countries [28]. Statistical methods, such as frequency ratio [29,30] and logistic regression [31], depend on predicted input variables, based on relations with various explanatory parameters, as well as on the size of datasets [30]. Furthermore, other advanced methods have been recently applied in flood susceptibility analysis, such as machine learning algorithms which may include random forest, artificial neural networks, or support vector machines [9,32-36].

However, each of the abovementioned approaches has certain weaknesses in terms of flood susceptibility mapping which may produce various uncertainties. Therefore, the selected methodology should sufficiently represent the spatially continuous and cumulative nature of the parameters' influence on flood-generating mechanisms. In addition, selection of an appropriate methodology for flood susceptibility mapping should also depend on the spatial scale (local, regional, national, or global).

The aim of this article is to present a methodology for identifying and assessing flood susceptible areas on a national scale of Slovakia using the analytical hierarchy process and GIS. In this study, flood susceptibility is seen as the predispositions of an area which are given by its physical configuration (excluding rainfall) that determines its propensity to flooding. The selection of conditioning factors tried to reflect different flood dynamics that occur in Slovakia. The weight linear combination approach was used to develop the final flood susceptibility classes. In addition, a GIS database of flood events, containing flood historical points in which at least one flood event occurred during the period 1997-2017, was used for validation purposes. 


\section{Materials and Methods}

\subsection{Study Area}

The study area was represented by the territory of Slovakia which is located in Central Europe. The whole territory covers $49,035 \mathrm{~km}^{2}$, as shown in Figure 1.

Slovakia belongs to two basic geomorphological units: Carpathian Mountains and Pannonian Basin. The climate has a continental nature belonging to the temperate zone. The long-term average temperature varies from 0 to $10{ }^{\circ} \mathrm{C}$ according to the region. Annual precipitation varies from $400 \mathrm{~mm}$ in the southern lowland areas up to $1000 \mathrm{~mm}$ in the mountainous regions. Slovakia lies on the watershed divide between the Black Sea and the Baltic Sea. The Danube River and its tributaries drain approximately $96 \%$ of the Slovak territory to the Black Sea. The remaining waters (approximately $4 \%$ ) are drained by the Vistula River tributaries to the Baltic Sea. Generally, watercourses in Slovakia have relatively unstable discharges-high discharges occur mainly in the spring months from March to April, while low discharges occur in summer and autumn. There are ten large sub-basins in the territory of Slovakia: Danube, Morava, Váh, Hron, Ipel', Slaná, Bodva, Hornád, Bodrog, Dunajec, and Poprad.

Larger Slovak rivers are usually exposed to fluvial flooding due to snow melting in the spring months from March to April or heavy long-term rains in the summer months from June to August (e.g., major fluvial floods occurred in 1997, 1998, 1999, and 2010). In most cases, floods on smaller rivers are caused by heavy short-term rainfall (flash floods) and develop rapidly. Flash floods affect mainly small watersheds or urban areas while pluvial flooding may occur at any place in Slovakia.

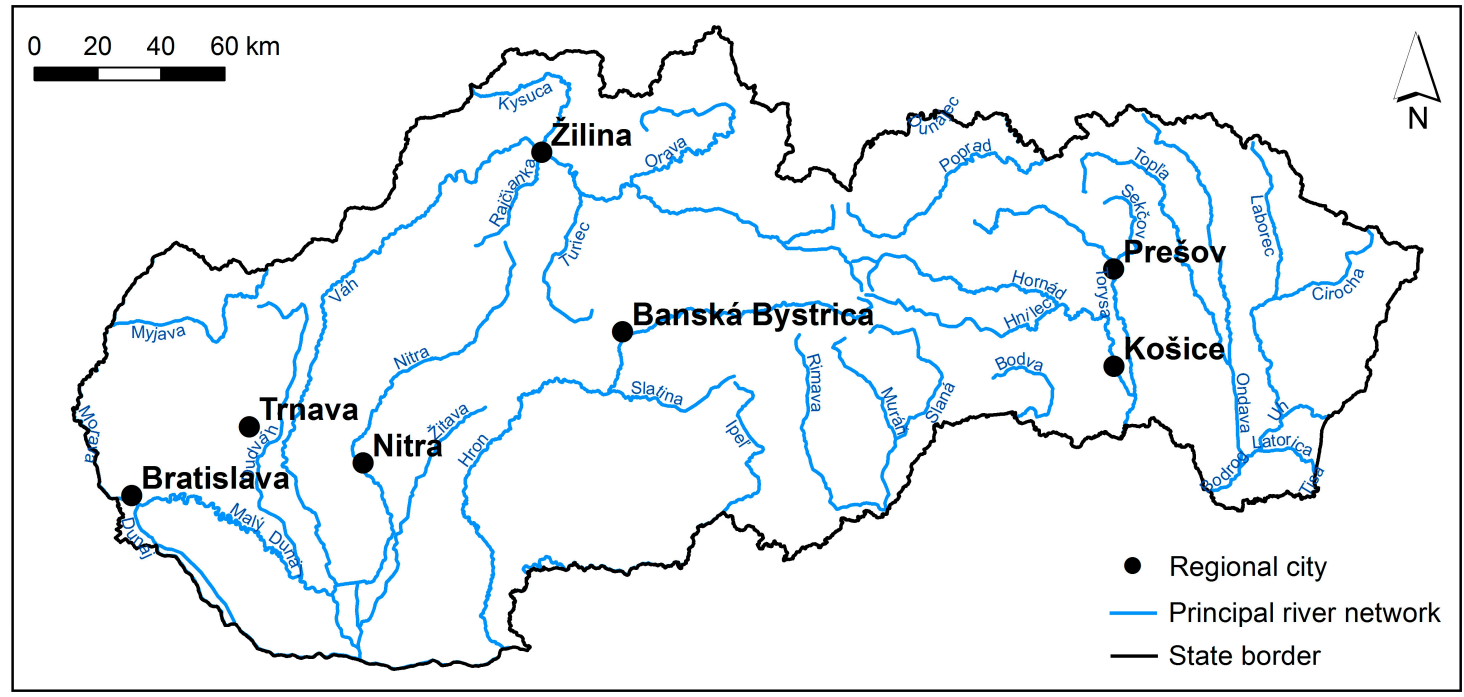

Figure 1. Study area.

\subsection{Flood Conditioning Factors and Methods of Their Processing}

Flood susceptibility mapping requires various input data which were collected from different sources and processed in GIS. The original data, which were used to process flood conditioning factors, and their sources are reported in Table 1. Based on a literature review (see Section 1) and relevance to flood susceptibility, seven flood conditioning factors were selected in order to capture appropriate information and avoid an unnecessary level of complexity in spatial modelling at the national scale: river network density, distance from rivers, as shown in Figure 2, elevation, slope, flow accumulation, as shown in Figure 3, curve number, and lithology, as shown in Figure 4 and Table 2. 
Table 1. Data sources used for processing of flood conditioning factors.

\begin{tabular}{lcc}
\hline \multicolumn{1}{c}{ Data } & Format & Source \\
\hline $\begin{array}{l}\text { River network } \\
\text { (Topographic map 1:50,000) }\end{array}$ & Vector (shapefile) & Geodetic and Cartographic Institute Bratislava \\
$\begin{array}{l}\text { Contour lines and elevation points } \\
\text { (Topographic map 1:50,000) }\end{array}$ & Vector (shapefile) & Geodetic and Cartographic Institute Bratislava \\
$\begin{array}{l}\text { Engineering-geological Zoning Map } \\
(1: 500,000)\end{array}$ & Vector (shapefile) & Landscape Atlas of the Slovak Republic \\
$\begin{array}{l}\text { Land cover } \\
\text { Soil Texture Map }\end{array}$ & Vector (shapefile) & CORINE land cover (2018) \\
$(1: 500,000)$ & Vector (shapefile) & Landscape Atlas of the Slovak Republic \\
\hline
\end{tabular}

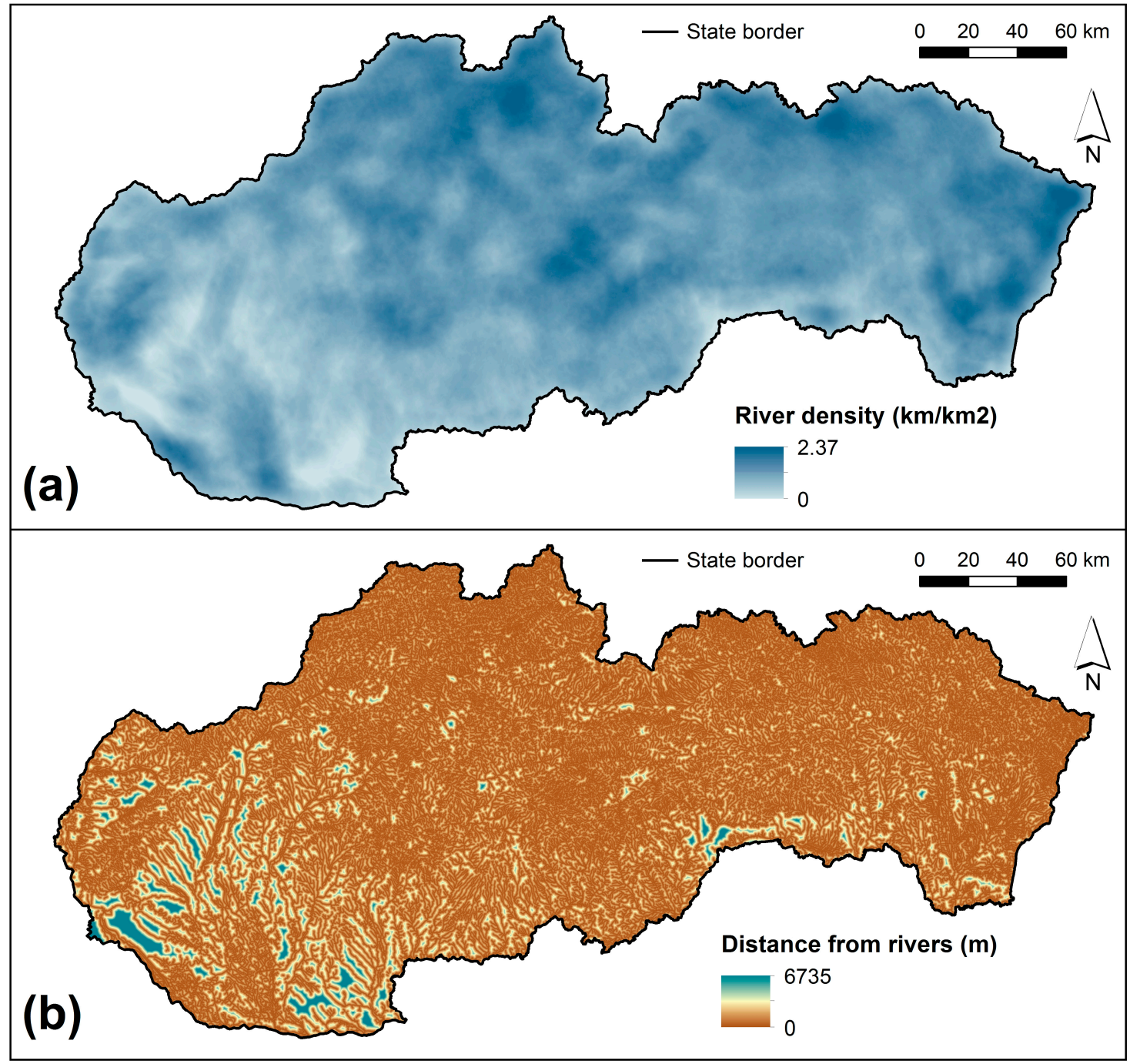

Figure 2. Flood conditioning factors: (a) river network density, (b) distance from rivers. 


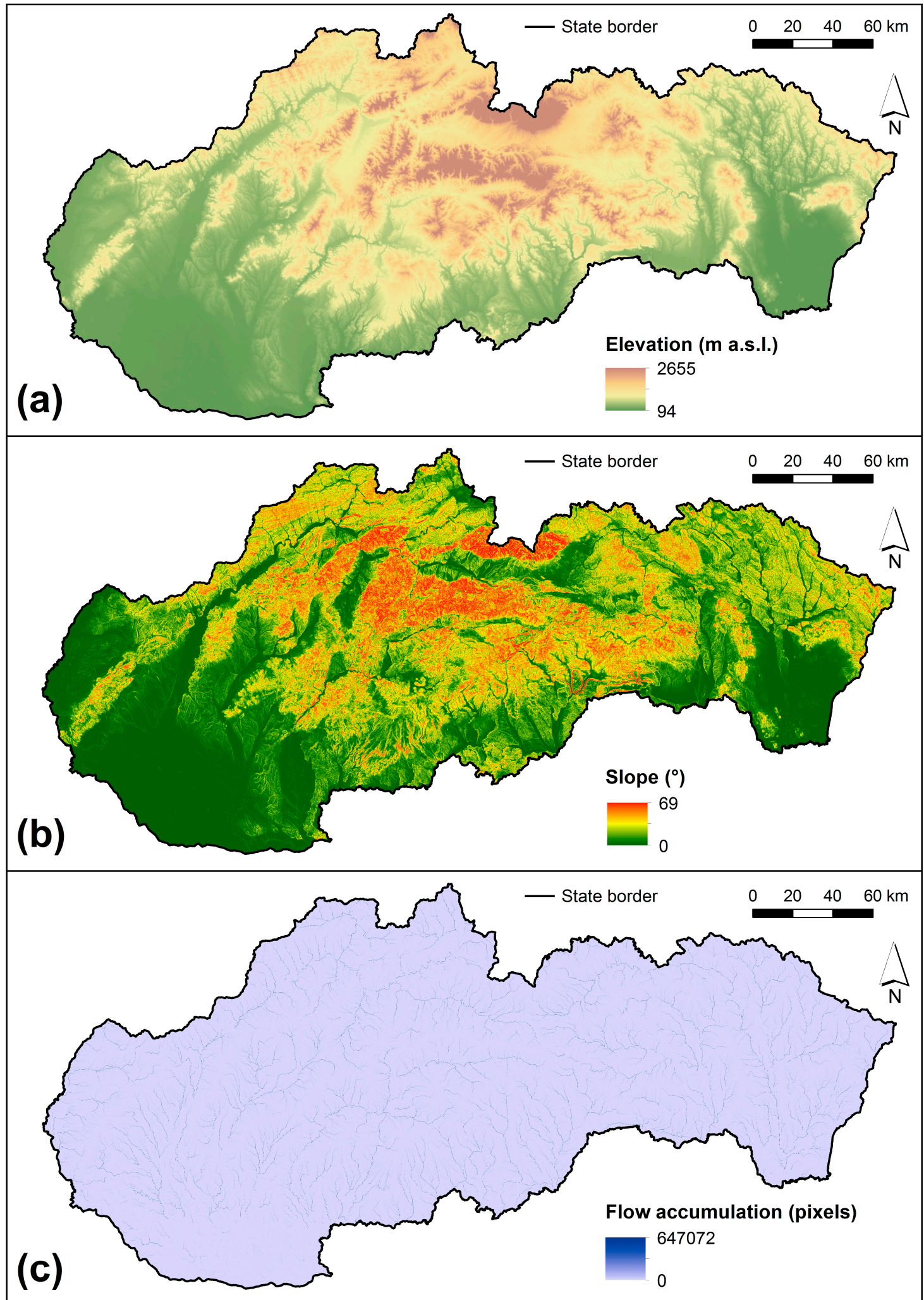

Figure 3. Flood conditioning factors: (a) elevation, (b) slope, (c) flow accumulation. 


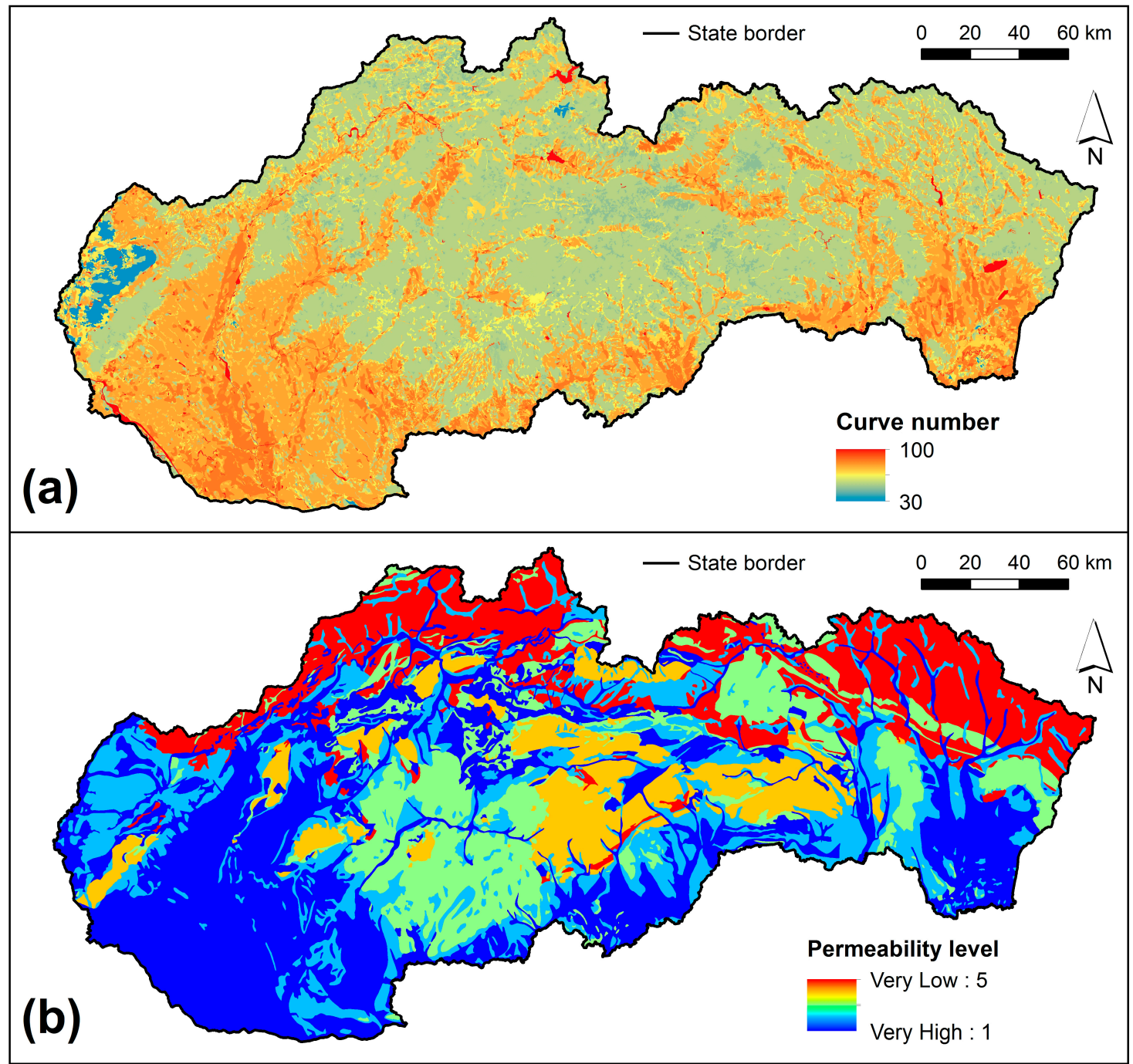

Figure 4. Flood conditioning factors: (a) curve number, (b) lithology.

Table 2. Classes of conditioning factors, estimated ratings, and relative importance.

\begin{tabular}{cccc}
\hline Factor & Class & Rating & Relative Importance \\
\hline & $0.0-2.0$ & 5 & \\
Slope $\left(^{\circ}\right)$ & $2.1-5.0$ & 4 & 7 \\
& $5.1-15.0$ & 3 & \\
& $15.1-35.0$ & 2 & \\
& $35<$ & 1 & \\
River network density $\left(\mathrm{km} / \mathrm{km}^{2}\right)$ & $0-0.69$ & 1 & \\
& $0.70-0.99$ & 2 & \\
& $1.00-1.25$ & 3 & \\
& $1.26-1.52$ & 4 & \\
& $1.53-2.37$ & 5 & \\
Distance from rivers $(\mathrm{m})$ & $<200$ & 5 & \\
& $201-500$ & 4 & \\
& $501-1000$ & 3 & \\
& $1001-2000$ & 2 & \\
& $2001<$ & 1 & \\
\hline
\end{tabular}


Table 2. Cont.

\begin{tabular}{|c|c|c|c|}
\hline Factor & Class & Rating & Relative Importance \\
\hline \multirow{5}{*}{ Flow accumulation (pixels) } & $0-250$ & 1 & \multirow{5}{*}{4} \\
\hline & $251-500$ & 2 & \\
\hline & $501-2500$ & 3 & \\
\hline & $2501-50,000$ & 4 & \\
\hline & $50,001-647,072$ & 5 & \\
\hline \multirow{4}{*}{ Elevation (m a.s.l.) } & $<300$ & 5 & \multirow{4}{*}{3} \\
\hline & $301-800$ & 4 & \\
\hline & $801-1500$ & 3 & \\
\hline & $1501-2655$ & 2 & \\
\hline \multirow{5}{*}{ Curve number } & $30-55$ & 1 & \multirow{5}{*}{2} \\
\hline & $56-65$ & 2 & \\
\hline & $66-75$ & 3 & \\
\hline & $76-85$ & 4 & \\
\hline & $86-100$ & 5 & \\
\hline \multirow{5}{*}{ Lithology (permeability level) } & Very High & 1 & \multirow{5}{*}{1} \\
\hline & High & 2 & \\
\hline & Moderate & 3 & \\
\hline & Low & 4 & \\
\hline & Very low & 5 & \\
\hline
\end{tabular}

In this study, raster-based analysis was used which means that vector conditioning factors (e.g., lithology) were converted to a raster format with the cell size of $50 \times 50 \mathrm{~m}$. All of the conditioning factors were processed in ArcGIS software using the S-JTSK Krovak East North coordinate system. In order for the conditioning factors to be comparable, they were reclassified to five susceptibility classes (5-very high, 4-high, 3-moderate, 2-low, and 1-very low) based on their potential contributions to flooding and other criteria mentioned in this sub-section, as shown in Table 2.

Due to rock permeability, thickness of the layers, and their outcrop size, lithology is an important conditioning factor which influences the hydrological processes in watersheds. The map of lithology was created based the vector Engineering-geological Zoning Map 1:500,000 [37] while the reclassification of the zones of pre-Quaternary and Quaternary rocks was performed using the level of rock permeability which was defined by Hrnčiarová [38]. Table 3 shows the zones of different rock types and their corresponding permeability level.

Table 3. Zones of rock types and their corresponding permeability level.

\begin{tabular}{lc}
\hline \multicolumn{1}{c}{ Zones of the Pre-Quaternary Rocks } & Permeability Level \\
\hline highly metamorphosed rocks & Low \\
epimetamorphosed rocks & Low \\
undivided metamorphosed rocks & Low \\
intrusive rocks & Low \\
effusive rocks & Moderate \\
volcanoclastic rocks & Moderate \\
undivided volcanic rocks & Moderate \\
conglomerate-sandstone rocks & Moderate \\
claystone-siltstone rocks & Moderate \\
flyschoid rocks & Very Low \\
limestone-dolomite rocks & Very High \\
claystone-limestone rocks & Moderate \\
undivided sedimentary rocks & High \\
gravel-sandy sediments & Very High \\
sandy sediments & Very High \\
clay-silty sediments & High \\
alternating clay-silty with sandy to gravel sediments & High \\
\hline
\end{tabular}


Table 3. Cont.

\begin{tabular}{lc}
\hline \multicolumn{1}{c}{ Zones of the Quaternary Sediments } & Permeability Level \\
\hline moraine deposits & High \\
glacio-fluvial deposits & High \\
colluvial deposits & High \\
deluvial deposits & High \\
proluvial deposits & High \\
floodplain deposits & Very High \\
river terrace deposits & High \\
aeolian sands & High \\
loess deposits & Very High \\
Quaternary carbonates & Very High \\
organic sediments & High \\
\hline
\end{tabular}

Elevation mostly affects flooding in an inverse way, i.e., flood frequency increases with decreasing elevation meaning that lower elevations are more susceptible to flooding [32]. The digital elevation model (DEM) was interpolated from contour lines and elevation points in the topographic map of 1:50,000 using a specific interpolation method for the creation of hydrologically correct DEMs [39]. The original hypsometric intervals were reclassified to four classes of susceptibility according to elevation levels defined by Lukniš [40].

Another significant physical predisposition for flooding is slope. The slope degree map was generated from the DEM. Moreover, slope classes used for reclassification were defined according to Demek [41].

Flow accumulation was derived from the flow direction raster. In the flow accumulation raster, each cell contains information on the number of cells that flow into it which means that each cell is also a discharge profile. In this sense, an increase in flow accumulation should reflect an increase in flood susceptibility. The classes of flow accumulation raster were defined in order that they best correspond to the vector layer of a river network at a scale of 1:50,000 which was also used for creating the hydrologically correct DEM.

Distance from rivers is another important conditioning factor since rivers and their adjacent lands are the main pathways for flooding. In this study, distance from rivers was calculated using the Euclidean distance tool in ArcGIS software based on the vector layer of a river network at a scale of 1:50,000. The classes for the raster of distance from rivers were adjusted according to the natural breaks (Jenks) grading method.

As for the river network density, higher density generally means increased surface runoff and thus increased probability of flooding. The map of river network density was developed in ArcGIS software based on the vector layer of a river network at a scale of 1:50,000. The classes of river network density were defined according to the natural breaks (Jenks) grading method.

Curve numbers (CN) were calculated using the SCS-CN method [42] and HEC-GeoHMS extension for ArcGIS software. Hydrological soil groups and land cover data represented the inputs for the calculation of CN. The map of hydrological soil groups [43] was created based on the Soil Texture Map 1:500,000 [44] while land cover data were derived from the CORINE land cover (CLC level 3) database for the year 2018 [45]. With the use of the SCS-CN table [43,46] and based on the map of hydrological soil groups as shown in Figure 5a, and the map of land cover as shown in Figure 5b, the resulting CN grid was obtained and reclassified into five classes according to the runoff potential of $\mathrm{CN}$ [47]. 


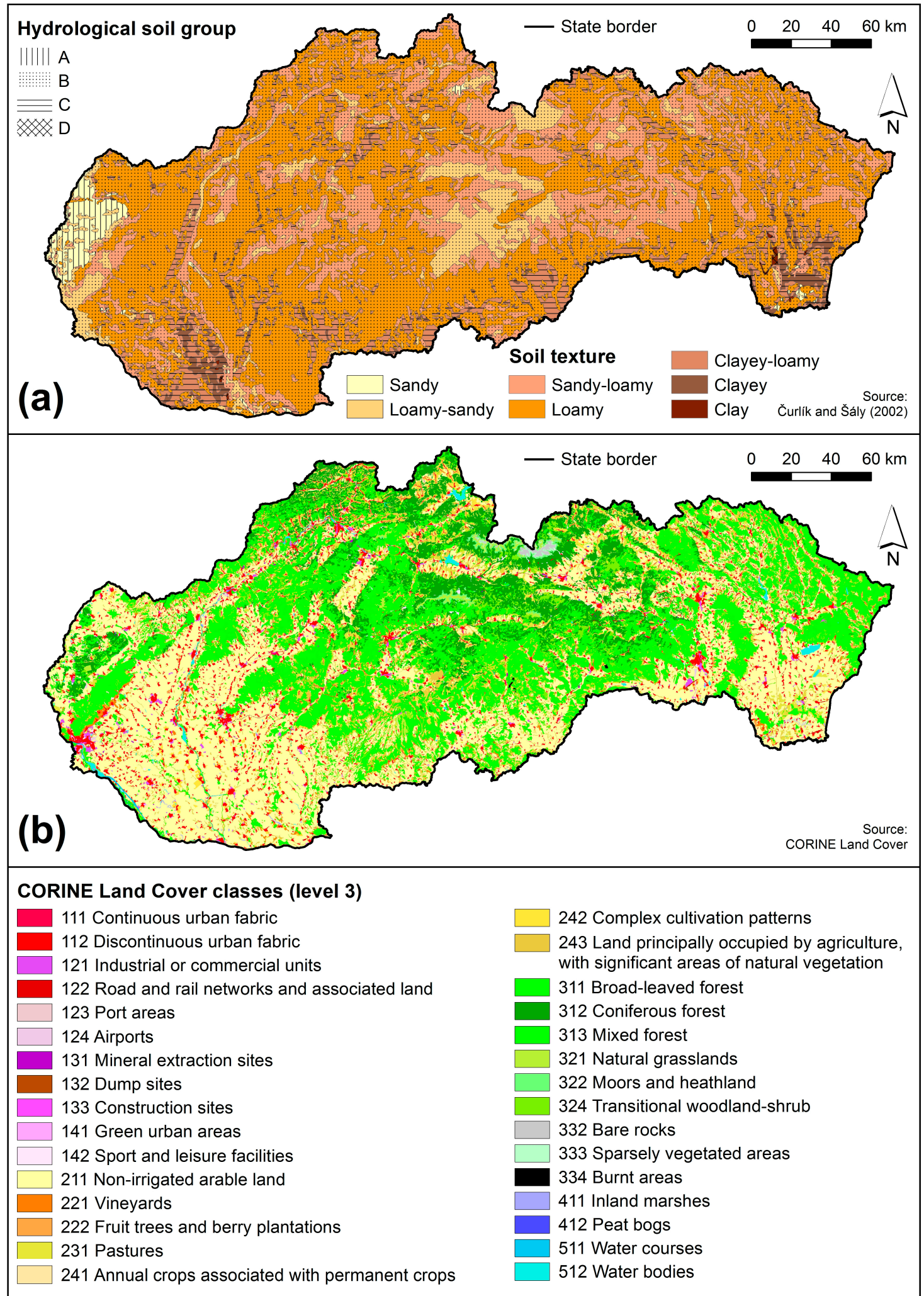

Figure 5. Soil texture and hydrological soil groups (a), CORINE land cover classes (2018) (b).

Since the purpose of this study was to reflect only the physical characteristics that influence flood susceptibility, rainfall data was not included in the set of flood conditioning factors. Moreover, rainfall is understood as a causal triggering factor which is more appropriate for local or regional scale analysis 
for which accurate rainfall observations can be applied, as compared to possible generalizations of rainfall data in case of national scale assessments.

\subsection{Weight Linear Combination Approach}

Using the weighted linear combination approach, the main steps were to define the relative significance of each criterion (factor) and their corresponding weights. The relative importance of the selected conditioning factors was assigned based on the empirical knowledge and recent studies $[21,32,34,35]$. It ranges from 7 (highest importance) to 1 (lowest importance), as shown in Table 2 . To estimate the weights for each criterion (factor), the technique of pairwise comparisons known as the AHP was used [20]. The weights were derived by taking the principal eigenvector of a square reciprocal $7 \times 7$ matrix of pairwise comparison between the criteria. Ratings of criteria were estimated by expert judgement and the literature review using the nine-point continuous scale [20]. The normalized pairwise comparison matrix and the final weights were calculated by the approximation method $[19,48]$, as shown in Table 4.

Table 4. Pair-wise comparison matrix, normalized factor weights, and final weights $\left(\mathrm{w}_{\mathrm{i}}\right)$.

\begin{tabular}{|c|c|c|c|c|c|c|c|c|}
\hline Factors & Slope & $\begin{array}{c}\text { River } \\
\text { Density }\end{array}$ & $\begin{array}{l}\text { Distance from } \\
\text { Rivers }\end{array}$ & $\begin{array}{c}\text { Flow } \\
\text { Accumulation }\end{array}$ & Elevation & $\begin{array}{c}\text { Curve } \\
\text { Number }\end{array}$ & Lithology & \\
\hline Slope & 1 & 2 & 3 & 4 & 5 & 6 & 7 & \\
\hline River density & 0.5 & 1 & 2 & 3 & 4 & 5 & 6 & \\
\hline $\begin{array}{l}\text { Distance from } \\
\text { rivers }\end{array}$ & 0.33 & 0.5 & 1 & 2 & 3 & 4 & 5 & \\
\hline $\begin{array}{l}\text { Flow } \\
\text { accumulation }\end{array}$ & 0.25 & 0.33 & 0.5 & 1 & 2 & 3 & 4 & \\
\hline Elevation & 0.2 & 0.25 & 0.33 & 0.5 & 1 & 2 & 3 & \\
\hline Curve number & 0.16 & 0.2 & 0.25 & 0.33 & 0.5 & 1 & 2 & \\
\hline Lithology & 0.14 & 0.16 & 0.2 & 0.25 & 0.33 & 0.5 & 1 & \\
\hline \multicolumn{9}{|c|}{ Normalized factor weights } \\
\hline Factors & Slope & $\begin{array}{c}\text { River } \\
\text { Density }\end{array}$ & $\begin{array}{l}\text { Distance from } \\
\text { Rivers }\end{array}$ & $\begin{array}{c}\text { Flow } \\
\text { Accumulation }\end{array}$ & Elevation & $\begin{array}{c}\text { Curve } \\
\text { Number }\end{array}$ & Lithology & $\begin{array}{c}\text { Weight } \\
\left(w_{i}\right)\end{array}$ \\
\hline Slope & 0.39 & 0.45 & 0.41 & 0.36 & 0.32 & 0.28 & 0.25 & 0.35 \\
\hline River density & 0.19 & 0.22 & 0.27 & 0.27 & 0.25 & 0.23 & 0.21 & 0.24 \\
\hline $\begin{array}{l}\text { Distance from } \\
\text { rivers }\end{array}$ & 0.13 & 0.11 & 0.14 & 0.18 & 0.19 & 0.19 & 0.18 & 0.16 \\
\hline $\begin{array}{l}\text { Flow } \\
\text { accumulation }\end{array}$ & 0.10 & 0.07 & 0.07 & 0.09 & 0.13 & 0.14 & 0.14 & 0.11 \\
\hline Elevation & 0.08 & 0.06 & 0.05 & 0.05 & 0.06 & 0.09 & 0.11 & 0.07 \\
\hline Curve number & 0.06 & 0.04 & 0.03 & 0.03 & 0.03 & 0.05 & 0.07 & 0.05 \\
\hline Lithology & 0.06 & 0.04 & 0.03 & 0.02 & 0.02 & 0.02 & 0.04 & 0.03 \\
\hline
\end{tabular}

Furthermore, the consistency ratio $(C R)$ was calculated in order to examine the consistency of the developed ratings using Equation (1):

$$
C R=\frac{C I}{R I}
$$

where $C R$ is the consistency ratio, $C I$ is the consistency index, and $R I$ is the random index which is dependent on the number of conditioning factors used in the pairwise matrix [20]. The consistency index $(C I)$ was calculated based on Equation (2):

$$
C I=\frac{\lambda-n}{n-1}
$$

where $n$ is the number of factors and $\lambda$ is the average value of the consistency vector. According to the AHP, the $C R$ should not be greater than 0.1 [20]. In this case, the calculated value of $C R$ is 0.02 which confirmed the consistency of ratings used.

The aggregation method (weighting sum) was used in order to multiply each reclassified factor map by its factor weight, as shown in Table 4, and sum the results (Equation (3)):

$$
F S=\sum w_{i} x_{i}
$$


where FS is flood susceptibility, $w_{i}$ is the weight of factor $i$, and $x_{i}$ represents classes of flood susceptibility for each factor $i$.

The calibration of factor weights was based on the comparison of different weighting results with the maps of geographic areas with potentially significant flood risk which were compiled by the Ministry of Environment of the Slovak Republic as a part of the preliminary flood risk assessment based on the Directive 2007/60/EC of the European Parliament and of the Council of 23 October 2007 on the Assessment and Management of Flood Risks. Different combinations of factor weights were tested in order to find the best coincidence with these areas.

\subsection{Flood Inventory Database}

A GIS database of flood events, containing flood historical points in which at least one flood event occurred during the period 1997-2017, was created in order to validate the results of flood susceptibility mapping. The information on flood occurrences during this period was collected from databases and flood reports of the Slovak Water Management Enterprise and the Slovak Hydrometeorological Institute as well as from the authors' personal records which were also based on field surveys. Altogether, 1513 flood historical points were mapped and digitized into the vector layer using ArcGIS software. However, it should be noted that this database does not contain all detected flood events, but only those for which the third level of flood activity was announced by one of the responsible authorities.

\section{Results}

After applying the weighting sum of all conditioning factors, the final map of flood susceptibility was obtained. The natural breaks (Jenks) grading method was used to classify the final flood susceptibility map, as shown in Figure 6. With regard to the AHP method, this grading method is considered to be the most appropriate for classifying flood susceptibility zones [49]. The calculated area of flood susceptibility zones and the share of flood events corresponding to individual flood susceptibility zones are presented in Table 5.

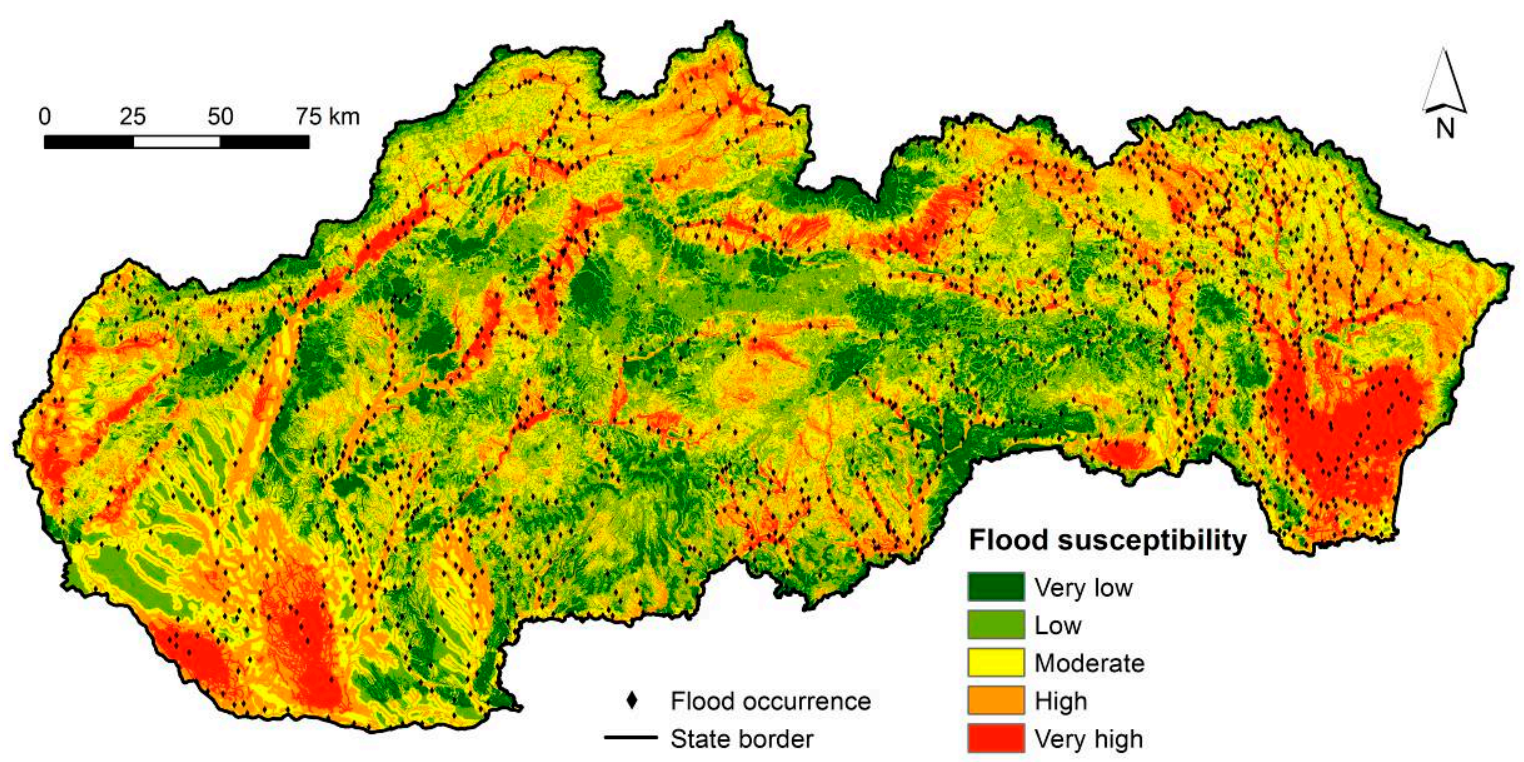

Figure 6. Flood susceptibility and flood historical points. 
Table 5. Area coverage of flood susceptibility classes and share of flood events corresponding to the defined flood susceptibility classes.

\begin{tabular}{lccc}
\hline Flood Susceptibility & Area $\left.\mathbf{( k m}^{\mathbf{2}}\right)$ & Area $\mathbf{( \% )}$ & Share of Flood Events $\mathbf{( \% )}$ \\
\hline Very low & 5469 & 11.2 & 0.3 \\
Low & 12,650 & 25.8 & 6.2 \\
Moderate & 14,681 & 29.9 & 22.5 \\
High & 10,755 & 21.9 & 37.1 \\
Very High & 5480 & 11.2 & 33.8 \\
\hline
\end{tabular}

As for the share of flood susceptibility classes (area percentage), the lowest share was recorded in the very high $(11.2 \%)$ and very low $(11.2 \%)$ classes. The high flood susceptibility class covers an area of $21.9 \%$ while the low susceptibility class recorded the share of $25.8 \%$. The highest share $(29.9 \%)$ can be seen in the moderate flood susceptibility class. In fact, $33.1 \%$ of the territory of Slovakia is characterized by very high to high flood susceptibility based on the incorporated conditioning factors and their final weights.

Furthermore, the flood susceptibility map was intersected with the CORINE land cover map from 2018 in order to find out the share of land cover classes (level 1) corresponding to the defined flood susceptibility classes. Table 6 shows the size and share of land cover classes out of their total areas corresponding to individual flood susceptibility classes. The share of the artificial surface class (1), out of the total area of this land cover class, corresponding to the high and very high susceptibility class was $33 \%$ and $24.66 \%$, respectively. As for the agricultural areas class (2), its share in the high susceptibility class slightly decreased to $30 \%$ while in case of the very high susceptibility, it decreased by $7.14 \%$. The least susceptible land cover class was the forest and semi natural areas (3) of which its share in the high susceptibility class was $11.76 \%$ while in case of the very high susceptibility class, it was only $2.39 \%$. Naturally, the most susceptible to floods are land cover classes of wetlands (4) and water bodies (5) of which their share in the high susceptibility class recorded $54.94 \%$ and $38.99 \%$, respectively, while in case of the very high susceptibility, the share was $34.01 \%$ and $43.91 \%$.

Table 6. Area coverage of land cover classes corresponding to the defined flood susceptibility classes. CLC: CORINE land cover.

\begin{tabular}{|c|c|c|c|c|c|c|c|c|c|c|c|c|}
\hline \multirow[b]{2}{*}{$\begin{array}{c}\text { CLC } \\
\text { (Level 1) }\end{array}$} & \multicolumn{11}{|c|}{ Flood Susceptibility Class } & \multirow[b]{2}{*}{$\begin{array}{c}\% \text { of Total } \\
\text { Area }\end{array}$} \\
\hline & $\mathrm{km}^{2}$ & $\%$ & $\mathrm{~km}^{2}$ & $\%$ & $\mathrm{~km}^{2}$ & $\%$ & $\mathrm{~km}^{2}$ & $\%$ & $\begin{array}{c}\mathrm{km}^{2} \\
5\end{array}$ & $\%$ & $\begin{array}{c}\text { Area } \\
\left(\mathrm{km}^{2}\right)\end{array}$ & \\
\hline 1 & 59.3 & 2.00 & 365.5 & 12.29 & 833.9 & 28.05 & 981.3 & 33.00 & 733.2 & 24.66 & 2973.2 & 6.06 \\
\hline 2 & 880.5 & 3.80 & 4091.1 & 17.68 & 7142.3 & 30.86 & 6973.6 & 30.13 & 4055.0 & 17.52 & $23,142.5$ & 47.20 \\
\hline 3 & 4528.7 & 20.07 & 8183.9 & 36.27 & 6656.1 & 29.50 & 2653.9 & 11.76 & 538.3 & 2.39 & $22,560.9$ & 46.01 \\
\hline 4 & 0.1 & 0.21 & 0.9 & 2.30 & 3.5 & 8.54 & 22.4 & 54.94 & 13.9 & 34.01 & 40.8 & 0.08 \\
\hline 5 & 0.5 & 0.14 & 8.6 & 2.70 & 45.3 & 14.26 & 123.8 & 38.99 & 139.5 & 43.91 & 317.6 & 0.65 \\
\hline
\end{tabular}

To verify the results achieved, the flood susceptibility map was compared against actual historical flood records, i.e., a flood occurrence point map. The results revealed very good agreement between the susceptibility maps and historical flood events, as shown in Figure 6. Out of 1513 historical flood events, which were collected from different sources, one third (33.8\%) of flood events occurred within the very high susceptibility level and $37.1 \%$ of historical floods were coincident with the high susceptibility level, as shown in Table 5. In addition, $22.5 \%$ of flood occurrences were recorded in the moderate flood susceptibility level while $6.2 \%$ of flood historical points lie in the low susceptibility level. Lastly, only $0.3 \%$ of recorded floods were found in the very low susceptibility level.

Altogether, $70.9 \%$ of all flood historical points were coincident with the high and very high susceptibility level. Based on this fact, it can be stated that the effectiveness of the methodology adopted, using the selected flood conditioning factors and their weights, proved to be well suited for defining flood susceptibility zones at the national scale of Slovakia. 


\section{Discussion}

Although the effectiveness of the methodology applied was confirmed by very good agreement between flood susceptibility zones and flood historical points, possible limitations and sources of uncertainties should be discussed.

The first arguable issue is the number of flood conditioning factors as well as the question of which factors should be chosen in order to best characterize the physical characteristics that determine the propensity of the study area to flooding. In this study, seven conditioning factors were selected similarly as in other flood susceptibility studies such as [50,51]. On the other hand, Samanta et al. [52] or Rahmati et al. [27] used only four parameters, while six parameters were used, for example, by Kourgialas and Karatzas [18]. Moreover, ten parameters were used, for example, by Haghizadeh et al. [53] and Khosravi et al. [21,49], eleven parameters by Choubin et al. [32], or twelve parameters by Zhao et al. [9]. As a result, it should be stated that no exact agreement exists on which factors should be applied for flood susceptibility analysis. However, Mahmoud and Gan [10] recommend using more than six factors in order to not produce unrepresentative weights dominated by a single weight which may increase the possibility of over-rating some of the flood contributing factors. The number of flood conditioning factors should be also adjusted with respect to the local geomorphologic and geologic conditions since flat areas may require other parameters than hilly (mountainous) areas.

In addition, some of the conditioning factors recur in each of the aforementioned studies and thus can be considered basic factors indicating their important role and relevance for flood susceptibility mapping. These basic factors are represented by slope, elevation, land use/land cover, distance from rivers/river network density, and lithology. In this study, the following proportional principle for selecting conditioning factors was used, incorporating also the basic conditioning factors: hydrography factors-river network density, distance from rivers (2); hydrological factors-flow accumulation (1); morphometric factors-elevation, slope (2); and permeability factors-curve numbers, lithology (2). In order to not underestimate or overestimate some category of factors, two factors in each category were used (except for flow accumulation). In this respect, the exclusion of causal rainfall factors from the set of flood conditioning factors might be also considered one of the possible limitations. However, as mentioned before, the purpose of this study was to reflect the physical (terrain) predispositions that influence flood-generation mechanisms. This approach was also presented in other studies, such as $[7,27,32,50,52,54]$.

In order to clarify if the proposed approach for flood susceptibility mapping is valid for mountainous or lowland (flat) areas, the analysis was performed aiming at finding the share of flood validation points (corresponding to different flood susceptibility levels) in mountainous and lowland (flat) areas. Based on Table 7, 944 (62.4\%) flood validation points lie in lowland areas (<300 m a.s.l.) while $569(37.6 \%)$ flood points were found in mountainous areas with altitudes higher than $300 \mathrm{~m}$ a.s.l. Regarding the slope, $766(50.6 \%)$ flood validation points relate to flat slopes from 0 to $2^{\circ}$ while $747(49.4 \%)$ flood points relate to slopes higher than $2^{\circ}$. Moreover, a similar share of flood validation points corresponding to very high or high flood susceptibility levels was found in mountainous (17.4\%—high/10.5\%—very high) and lowland areas (23.3\%—high/7.2\%—very high). As for the number of flood validation points corresponding to very high or high flood susceptibility levels and their localization based on the slope map, $20.8 \%$ (high) $/ 8.5 \%$ (very high) flood validation points lie in mountainous areas with slopes between 2 and $69^{\circ}$ while $20.0 \%$ (high) $/ 9.2 \%$ (very high) flood validation points lie in flat areas with slopes between 0 and $2^{\circ}$. Based on this analysis, the presented methodology was found to be valid both for mountainous and lowland (flat) areas. 
Table 7. Flood validation points and their share in mountainous/lowland (flat) areas.

\begin{tabular}{lccc}
\hline $\begin{array}{c}\text { Mountainous/Lowland } \\
\text { Area }\end{array}$ & $\begin{array}{c}\text { Flood Susceptibility } \\
\text { Level }\end{array}$ & $\begin{array}{c}\text { Number of Flood } \\
\text { Validation Points }\end{array}$ & $\begin{array}{c}\text { \% of Total Number of } \\
\text { Flood Validation Points }\end{array}$ \\
\hline & Very low & 2 & 0.1 \\
Mountainous & Low & 28 & 1.9 \\
$($ elevation $>300$ m a.s.l.) & Moderate & 116 & 7.7 \\
& High & 264 & 17.4 \\
& Very high & 159 & 10.5 \\
\hline & Very low & 18 & 1.2 \\
Lowland & Low & 195 & 12.9 \\
$($ elevation $<300$ m a.s.l.) & Moderate & 270 & 17.8 \\
& High & 352 & 23.3 \\
& Very high & 109 & 7.2 \\
\hline & Very low & 5 & 0.3 \\
Mountainous & Low & 92 & 6.1 \\
$\left(\right.$ slope $\left.2-69^{\circ}\right)$ & Moderate & 207 & 13.7 \\
& High & 314 & 20.8 \\
& Very high & 129 & 8.5 \\
\hline & Very low & 15 & 1.0 \\
Lowland $/$ flat & Low & 131 & 8.6 \\
(slope 0-2 $\left.{ }^{\circ}\right)$ & Moderate & 179 & 11.8 \\
& High & 302 & 20.0 \\
& Very high & 139 & 9.2 \\
\hline
\end{tabular}

Furthermore, the selection of flood conditioning factors also depends on the spatial scale of the intended flood susceptibility analysis which may range from local [11] to global [55]. Here, the main problem was the input data sources which usually have a different original scale, resolution, or generalization. This is particularly true in the case of national scale assessments when obtaining input data with the same spatial accuracy or generalization is difficult, as confirmed also by these studies [7-9].

Another important issue in defining the flood susceptibility zones using the MCDA is the process of assigning relative importance for the selected conditioning factors. In this study, slope degree was assigned the highest relative importance indicating that slope is the most important conditioning factor for finding areas susceptible to flooding. The relative significance of the rest of the conditioning factors used in this study decreases as follows: river network density, distance from rivers, flow accumulation, elevation, curve number, lithology. A similar approach in prioritizing the flood conditioning factors was used and verified also in other studies such as [32,36].

As a result, flood susceptibility mapping, particularly on a national or larger scale, requires the resolution of the problem of finding the optimal balance between the complexity of the flood susceptibility model and the accuracy and quantity of the input data. Therefore, future work will address the challenges associated with data consolidation, in terms of the original scale, resolution, or generalization, as well as their integration. Moreover, an emphasis will be placed on comparing the AHP technique with other methods (mentioned in Section 1) for assessing flood susceptibility in order to find the most suitable alternative also with respect to more robust compilation of validation data, i.e., inventory of flood events.

\section{Conclusions}

The presented study aimed to define the flood susceptibility zones for the territory of Slovakia using MCDA, particularly the AHP technique, and GIS. Seven flood conditioning factors were chosen in order to capture the complexity of physical configuration of the territory of Slovakia. The equal proportional principle for the selection of flood conditioning factors was used and the following factors were selected: two hydrography factors-river network density, distance from rivers; one hydrological factor-flow accumulation; two morphometric factors-elevation, slope; and two 
permeability factors-curve numbers, lithology. All flood conditioning factors were defined in GIS as raster datasets with the spatial resolution of $50 \times 50 \mathrm{~m}$.

The AHP technique was used to calculate the factor weights based on Saaty's [20] nine-point scale of influence. The relative importance of the selected conditioning factors prioritized the slope degree as the most important factor for finding areas susceptible to flooding, followed by river network density, distance from rivers, flow accumulation, elevation, curve number, and lithology. Finally, the aggregation method was used to combine the reclassified factors and produce the resulting flood susceptibility map which contains five classes: very low, low, moderate, high, and very high susceptibility.

Furthermore, the flood susceptibility map was compared against the flood historical points showing very good agreement between the susceptibility zones and historical flood events of which $70.9 \%$ were coincident with high or very high susceptibility levels, thus confirming the effectiveness of the methodology adopted. Finally, the presented approach for flood susceptibility analysis on a national scale can provide a suitable alternative for the review of preliminary flood risk assessment and identification of potential significant flood risk in Slovakia, which should be updated every six years [56].

Author Contributions: Both authors contributed to the conception of the study. Matej Vojtek designed the methodology and wrote majority of the manuscript. Jana Vojteková assembled and processed the input data, visualized and validated the results, and participated in manuscript writing.

Funding: This research was supported by the VEGA agency (Scientific Grant Agency of the Ministry of Education, Science, Research and Sport of the Slovak Republic and the Slovak Academy of Sciences), grant number 1/0934/17 and the University Grant Agency (UGA) of Constantine the Philosopher University in Nitra.

Conflicts of Interest: The authors declare no conflict of interest.

\section{References}

1. Kundzewicz, Z.W.; Pińskwar, I.; Brakenridge, G.R. Large floods in Europe, 1985-2009. Hydrol. Sci. J. 2013, 58, 1-7. [CrossRef]

2. Hirabayashi, Y.; Mahendran, R.; Koirala, S.; Konoshima, L.; Yamazaki, D.; Watanabe, S.; Kim, H.; Kanae, S. Global flood risk under climate change. Nat. Clim. Chang. 2013, 3, 816. [CrossRef]

3. Sofia, G.; Roder, G.; Dalla Fontana, G.; Tarolli, P. Flood dynamics in urbanised landscapes: 100 years of climate and humans' interaction. Sci. Rep. 2017, 7, 40527. [CrossRef]

4. Fohrer, N.; Haverkamp, S.; Eckhardt, K.; Frede, H.G. Hydrologic response to land use changes on the catchment scale. Phys. Chem. Earth. 2001, 26, 577-582. [CrossRef]

5. Costache, R.; Fontanine, F.; Corodescu, E. Assessment of surface runoff depth changes in Sărăţel River basin, Romania using GIS techniques. Cent. Eur. J. Geosci. 2014, 6, 363-372.

6. Adger, N.W. Vulnerability. Glob. Environ. Chang. 2006, 16, 268-281. [CrossRef]

7. Jacinto, R.; Grosso, N.; Reis, E.; Dias, L.; Santos, F.D.; Garrett, P. Continental Portuguese Territory Flood Susceptibility Index-Contribution to a vulnerability index. Nat. Hazards Earth Syst. Sci. 2015, 15, 1907-1919. [CrossRef]

8. Kourgialis, N.N.; Karatzas, G.P. A national scale flood hazard mapping methodology: The case of Greece-Protection and adaptation policy approaches. Sci. Total Environ. 2017, 601-602, 441-452. [CrossRef]

9. Zhao, G.; Pang, B.; Xu, Z.; Yue, J.; Tu, T. Mapping flood susceptibility in mountainous areas on a national scale in China. Sci. Total Environ. 2018, 615, 1133-1142. [CrossRef]

10. Mahmoud, S.H.; Gan, T.Y. Multi-criteria approach to develop flood susceptibility maps in arid regions of Middle East. J. Clean. Prod. 2018, 196, 216-229. [CrossRef]

11. Santangelo, N.; Santo, A.; Di Crescenzo, G.; Foscari, G.; Liuzza, V.; Sciarrotta, S.; Scorpio1, V. Flood susceptibility assessment in a highly urbanized alluvial fan: The case study of Sala Consilina (southern Italy). Nat. Hazards Earth. Syst. Sci. 2011, 11, 2765-2780. [CrossRef]

12. Cao, C.; Xu, P.; Wang, Y.; Chen, J.; Zheng, L.; Niu, C. Flash Flood Hazard Susceptibility Mapping Using Frequency Ratio and Statistical Index Methods in Coalmine Subsidence Areas. Sustainability 2016, 8, 948. [CrossRef] 
13. Carver, S.J. Integrated multi-criteria evaluation with geographical information systems. Int. J. Geogr. Inf. Syst. 1991, 5, 321-339. [CrossRef]

14. Eastman, J.R.; Weigen, J.; Kyem, P.A.; Toledano, J. Raster procedures for multi-criteria/multi-objective decisions. Photogram. Eng. Remote Sens. 1995, 61, 539-547.

15. Hu, S.; Cheng, X.; Zhou, D.; Zhang, H. GIS-based flood risk assessment in suburban areas: A case study of the Fangshan District, Beijing. Nat. Hazards 2017, 87, 1525-1543. [CrossRef]

16. Souissi, D.; Zouhri, L.; Hammami, S.; Msaddek, M.H.; Zghibi, A.; Dlala, M. GIS-based MCDM-AHP modeling for flood susceptibility mapping of arid areas, southeastern Tunisia. Geocarto Int. 2019, 1-25. [CrossRef]

17. Tang, Z.; Zhang, H.; Yi, S.; Xiao, Y. Assessment of flood susceptible areas using spatially explicit, probabilistic multi-criteria decision analysis. J. Hydrol. 2018, 558, 144-158. [CrossRef]

18. Kourgialas, N.N.; Karatzas, G.P. Flood management and a GIS modelling method to assess flood-hazard areas-A case study. Hydrol. Sci. J. 2011, 56, 212-225. [CrossRef]

19. Drobne, S.; Lisec, A. Multi-attribute decision analysis in GIS: Weighted linear combination and ordered weighted averaging. Informatica 2009, 33, 459-474.

20. Saaty, T.L. The Analytic Hierarchy Process; Mc Graw Hill Company: New York, NY, USA, 1980.

21. Khosravi, K.; Pourghasemi, H.R.; Chapi, K.; Bahri, M. Flash flood susceptibility analysis and its mapping using different bivariate models in Iran: A comparison between Shannon's entropy, statistical index, and weighting factor models. Environ. Model. Assess. 2016, 188, 656. [CrossRef]

22. Nardi, F.; Vivoni, E.R.; Grimaldi, S. Investigating a floodplain scaling relation using a hydrogeomorphic delineation method. Water Resour. Res. 2006, 42, 1-15. [CrossRef]

23. Degiorgis, M.; Gnecco, G.; Gorni, S.; Roth, G.; Sanguineti, M.; Taramasso, A.C. Classifiers for the detection of flood-prone areas using remote sensed elevation data. J. Hydrol. 2012, 470-471, 302-315. [CrossRef]

24. Gnecco, G.; Morisi, R.; Roth, G.; Sanguineti, M.; Taramasso, A.C. Supervised and semi-supervised classifiers for the detection of flood-prone areas. Soft Comp. 2017, 21, 3673-3685. [CrossRef]

25. Samela, C.; Albano, R.; Sole, A.; Manfreda, S. A GIS tool for cost-effective delineation of flood-prone areas. Comp. Environ. Urb. Syst. 2018, 70, 43-52. [CrossRef]

26. Sole, A.; Giosa, L.; Albano, R.; Cantisani, A. The laser scan data as a key element in the hydraulic flood modelling in urban areas. Int. Arch. Photogramm. Remote Sens. Spat. Inf. Sci. 2013, XL-4/W1, 65-70. [CrossRef]

27. Rahmati, O.; Zeinivand, H.; Besharat, M. Flood hazard zoning in Yasooj region, Iran, using GIS and multi-criteria decision analysis. Geomat. Nat. Hazards Risk 2016, 7, 1000-1017. [CrossRef]

28. Albano, R.; Sole, A. Geospatial Methods and Tools for Natural Risk Management and Communications. ISPRS Int. J. Geo-Inf. 2018, 7, 470. [CrossRef]

29. Samanta, S.; Kumar Pal, D.; Palsamanta, B. Flood susceptibility analysis through remote sensing, GIS and frequency ratio model. Appl. Water Sci. 2018, 8, 66. [CrossRef]

30. Siahkamari, S.; Haghizadeh, A.; Zeinivand, H.; Tahmasebipour, N.; Rahmati, O. Spatial prediction of flood-susceptible areas using frequency ratio and maximum entropy models. Geocarto Int. 2018, 33, 1-15. [CrossRef]

31. Pradhan, B. Flood susceptible mapping and risk area delineation using logistic regression, GIS and remote sensing. J. Spat. Hydrol. 2010, 9, 1-18.

32. Choubin, B.; Moradi, E.; Golshan, M.; Adamowski, J.; Sajedi-Hosseini, F.; Mosavi, A. An ensemble prediction of flood susceptibility using multivariate discriminant analysis, classification and regression trees, and support vector machines. Sci. Total Environ. 2019, 651, 2087-2096. [CrossRef] [PubMed]

33. Tehrany, M.S.; Pradhan, B.; Jebur, M.N. Flood susceptibility analysis and its verification using a novel ensemble support vector machine and frequency ratio method. Stoch. Environ. Res. Risk. Assess. 2015, 29, 1149-1165. [CrossRef]

34. Bui, D.T.; Pradhan, B.; Nampak, H.; Bui, Q.T.; Tran, Q.A.; Nguyen, Q.P. Hybrid artificial intelligence approach based on neural fuzzy inference model and metaheuristic optimization for flood susceptibility modeling in a high-frequency tropical cyclone area using GIS. J. Hydrol. 2016, 540, 317-330.

35. Hong, H.; Panahi, M.; Shirzadi, A.; Ma, T.; Liu, J.; Zhu, A.X.; Kazakis, N. Flood susceptibility assessment in Hengfeng area coupling adaptive neuro-fuzzy inference system with genetic algorithm and differential evolution. Sci. Total Environ. 2018, 621, 1124-1141. [CrossRef] [PubMed] 
36. Termeh, S.V.R.; Kornejady, A.; Pourghasemi, H.R.; Keesstra, S. Flood susceptibility mapping using novel ensembles of adaptive neuro fuzzy inference system and metaheuristic algorithms. Sci. Total Environ. 2018, 615, 438-451. [CrossRef] [PubMed]

37. Hraš;na, M.; Klukanová, A. Engineering-geological zoning. In Landscape Atlas of the Slovak Republic; Hrnčiarová, T., Ed.; MŽP SR, SAŽP: Bratislava, Banská Bystrica, Slovakia, 2002; p. 83.

38. Hrnčiarová, T. Hodnotenie potenciálnej zranitel'nosti zásob podzemných vôd pre ekologické plánovanie krajiny [Assessing the potential vulnerability of groundwater resources for ecological landscape planning]. Životné Prostredie 1993, 27, 311-314. (In Slovak)

39. Hutchinson, M.F. Calculation of hydrologically sound digital elevation models. In Proceedings of the Third International Symposium on Spatial Data Handling, Sydney, Australia, 17-19 August 1988; International Geographical Union: Sydney, Australia, 1988.

40. Lukniš, M. Reliéf [Relief]. In Slovensko 2-Príroda; Lukniš, M., Ed.; Obzor: Bratislava, Slovakia, 1972; pp. 124-202. (In Slovak)

41. Demek, J. Manual of Detailed Geomorphological Mapping; Academia: Prague, Czechia, 1972.

42. SCS (Soil Conservation Service). National Engineering Handbook, Section 4; U.S. Department of Agriculture: Washington, DC, USA, 1972.

43. Chow, V.T. Handbook of Applied Hydrology; McGraw-Hill Book Company: New York, NY, USA, 1964.

44. Čurlík, J.; Šály, R. Soil texture. In Landscape Atlas of the Slovak Republic; Hrnčiarová, T., Ed.; MŽP SR, SAŽP: Bratislava, Banská Bystrica, Slovakia, 2002; p. 111.

45. European Commission. CORINE (Coordination of Information on Environment) Database, a Key Database for European Integrated Environmental Assessment; Programme of the European Commission, European Environmental Agency (EEA): Copenhagen, Denmark, 2000.

46. Cronshey, R.; McCuen, R.H.; Miller, N.; Rawls, W.; Robbins, S.; Woodward, D. Urban Hydrology for Small Watersheds (TR-55); Natural Resources Conservation Service: Washington, DC, USA, 1986.

47. Vojtek, M.; Vojteková, J. GIS-based approach to estimate surface runoff in small catchments: A case study. Quaestiones Geographicae 2016, 35, 97-116. [CrossRef]

48. Malczewski, J. GIS and Multicriteria Decision Analysis; John Wiley and Sons: Toronto, ON, Canada, 1999.

49. Khosravi, K.; Nohani, E.; Maroufinia, E.; Pourghasemi, H.R. A GIS-based flood susceptibility assessment and its mapping in Iran: A comparison between frequency ratio and weights-of-evidence bivariate statistical models with multi-criteria decision-making technique. Nat. Hazards 2016, 83, 947-987. [CrossRef]

50. Elkhrachy, I. Flash Flood Hazard Mapping Using Satellite Images and GIS Tools: A case study of Najran City, Kingdom of Saudi Arabia (KSA). Egypt. J. Remote. Sens. Space Sci. 2015, 18, 261-278. [CrossRef]

51. Kazakis, N.; Kougias, I.; Patsialis, T. Assessment of flood hazard areas at a regional scale using an index-based approach and Analytical Hierarchy Process: Application in Rhodope-Evros region, Greece. Sci. Total Environ. 2015, 538, 555-563. [CrossRef]

52. Samanta, S.; Koloa, C.; Kumar Pal, D.; Palsamanta, B. Flood Risk Analysis in Lower Part of Markham River Based on Multi-Criteria Decision Approach (MCDA). Hydrology 2016, 3, 29. [CrossRef]

53. Haghizadeh, A.; Siahkamari, S.; Hamzeh Haghiabi, A.; Rahmati, O. Forecasting flood-prone areas using Shannon's entropy model. J. Earth Syst. Sci. 2017, 126, 39. [CrossRef]

54. Costache, R. Flash-Flood Potential assessment in the upper and middle sector of Prahova river catchment (Romania). A comparative approach between four hybrid models. Sci. Total Environ. 2019, 659, 1115-1134. [CrossRef]

55. De Roo, A.; Barredo, J.; Lavalle, C.; Bodis, K.; Bonk, R. Potential Flood Hazard and Risk Mapping at Pan-European Scale. In Digital Terrain Modelling, Lecture Notes in Geoinformation and Cartography; Jordan, G., Ed.; Springer: Berlin/Heidelberg, Germany, 2007; pp. 183-202.

56. European Parliament. Directive 2007/60/EC of the European Parliament and of the Council of 23 October 2007 on the Assessment and Management of Flood Risks. 2007. Available online: http:/ / ec.europa.eu/ environment/water/flood_risk/key_docs.htm\#Directive (accessed on 15 January 2019).

(C) 2019 by the authors. Licensee MDPI, Basel, Switzerland. This article is an open access article distributed under the terms and conditions of the Creative Commons Attribution (CC BY) license (http:/ / creativecommons.org/licenses/by/4.0/). 